\title{
Situating Indianité: Exile, Marginalization, and Memory in Ernest Moutoussamy's Aurore
}

\section{Shanaaz MOHAMMED}

Florida State University

$\mathrm{E}$ xile, as an experience and a trope, frames the French Caribbean lived experience. Edouard Glissant, for instance, writes in his Le discours antillais (1981) that exile has been and remains a defining feature of the French Caribbean people: 'C $C$ 'est que l'exil est en nous, dès le premier jour, et d'autant plus usant que nous n'avons pas encore appris à le débusquer sous nos frêles assurances ni n'avons tous d'un seul tenant réussi à le terrer, ici. Toute la poésie antillaise en a rendu compte" (45354). Allusions to physical and cultural displacement and its associated sentiments of loss, nostalgia, and a desire to return to one's native land ceaselessly inform literary explorations into the French Caribbean existence. From Négritude to Antillanité and Créolité, all (French) Caribbean writing, as J. Michael Dash observes, is inscribed with the "existential experience of exile and the essentialist temptation of home" (451). In this article, I examine the French Caribbean exilic experience from the perspective of the understudied East Indian diaspora. Using Ernest Moutoussamy's second novel, Aurore (1987), as my primary object of study, I discuss the representation of the East Indian diasporic condition from India to the French Caribbean, specifically Guadeloupe. I consider Aurore as a literary site of what Marianne Hirsch calls "postmemory," through which Moutoussamy remembers the East Indian laborers' exilic experience and situates it within French Caribbean historicity. I contend that though 
this novel is a foundational text that writes this diaspora's experience in the French Caribbean literary imaginary, it simultaneously dismisses the spatio-temporal shift from India to Guadeloupe and recreates boundaries that contribute to the diaspora's marginalized existence.

Arriving as indentured laborers during the latter half of the nineteenth century, the East Indian diaspora in Guadeloupe occupies a marginal space in literary and critical writings from the French Caribbean. This diaspora, the majority of whom were recruited from Indian settlements under French possession at the time such as Madras, Pondicherry, Karikal, Yanaon, Chandernagor, and Mahé, constituted a cheap source of labor replacement for the French plantation owners during the post-slavery era. The East Indian laborers were contracted to work for a minimum period of five years and had the right to repatriate at the end of their service. Of the estimated 42,000 laborers that arrived between 1854 and 1889 in Guadeloupe, it is reported that roughly 8,000 returned to India (Moutoussamy La Guadeloupe 15). For those who decided to stay in the already socio-economically and racially hierarchized Guadeloupean society - wherein the white planter class occupied the upper echelons, followed by the mixed-race middle class and the former slaves positioned at the bottom of the pyramid - it meant that they were positioned de facto at the lowest level of the hierarchy.

The Indo-French Caribbeans' historical and social marginalization coupled with their ethnic minority status (persons of East Indian descent account for approximately $15 \%$ of the Guadeloupean population) bled into their non-recognition in literary and critical discourses. Their presence is isolated to mere references, for instance, Aimé Césaire's brief allusion to "un homme-hindou-de-Calcutta" (12) in his classic prose poem Cahier d'un retour au pays natal, first published in 1939. Moreover, the cultural identity paradigms that have shaped critical discourses on the French Caribbean (such as Négritude advanced from the 1930s by Césaire, Léopald Sédar Senghor, and Léon-Gontran Damas as well as Antillanité, developed by Edouard Glissant from the 1960s) tend to pay more attention to the African diaspora. More recent theoretical engagements with French Caribbean cultural identity models, such as Créolité, spearheaded by Jean Bernabé, Patrick Chamoiseau and Raphaël Confiant, recognize the presence of soi-disant minority cultures, including those of the East Indian diaspora. However, in spite of its all-inclusive tagline "Ni Européens, ni Africains, ni Asiatiques, nous nous proclamons Créoles" (13), Créolité subsumes the specificity of these people and their cultures under the universalizing designation "Créole." By gesturing towards a unified creole identity, this 
cultural project fails to fully engage with the distinctive aspects of the racial and cultural diversity at work in the French Caribbean.

The early 1970s and especially the 1980s saw an increase in the attention accorded to the East Indian diaspora in literature and critical theory from the French Caribbean. This modification in this diaspora's representation came with the introduction of the concept of Indianité, first proposed by the Martinican researcher, Gilbert Francis Ponaman, and further developed by the Guadeloupean author and politician, Ernest Moutoussamy. Born out of a need to break the literary and theoretical silencing surrounding the East Indian diaspora's cultural and physical presence, Indianité, roughly translated as Indianness, refers to a cultural expression of East Indian cultural heritage that exists and flourishes in Guadeloupe, which in turn inevitably adds to the multiplicity of races and cultures characteristic of the Guadeloupean reality. Moutoussamy, the first author to engage meaningfully with the Indo-Guadeloupeans, discusses his conceptualization of Indianité in more detail in his La Guadeloupe et son Indianité (1987). He defines it as “...l'expression de l'attachement à l'Inde, de ses valeurs, de sa culture. Elle est un message de reconnaissance, le fruit d'un héritage. C'est un souffle culturel et historique qui transcende les frontières de race et de pays" (23). Through this concept of Indianité, Moutoussamy brings the East Indian diaspora's presence out of its historical amnesia. The notion of Indianité thus seeks to conceptualize this diaspora's physical and cultural reality, render its presence visible in the literary, political, and social domains, and situate its presence in relation to the already existing cultural movements of Négritude, Antillanité, and Créolité. Moutoussamy's oeuvre, which comprises several poetry collections, novels as well as essays, therefore, represents a point of departure from which the Indo-French-Caribbean diaspora can be explored in an attempt to simultaneously enrich and complicate the aforementioned cultural identity models. His works additionally constitute a paradigm shift since they add a new dimension in cultural production from the French Caribbean by shedding light on the often-ignored East Indian diaspora, a presence that is encapsulated in Aurore.

Given its portrayal of the Indo-French Caribbeans' diasporic experience, Aurore forms part of what Brinda Mehta calls kala pani literary narratives, which "...chronicle the history of indenture and the experiences of indentured Indians" (1). In addition to Moutoussamy's works, this network of literature on the Indo-French Caribbeans has been extended in recent years, as novelists include characters of East Indian origin, such as the Ramsaran family in Maryse Condé's Traversée de la mangrove (1989), 
or, dedicate full novels that explore the East Indians' exilic experience in Martinique, like Raphaël Confiant's La panse du chacal (2004). The East Indian presence is additionally highlighted through mixed-race characters such as Arlette Minatchy-Bogat's Louisiane in her La métisse caribéenne (2004). By depicting the East Indian diaspora, these works engage in a process of remembering and re-inscribe this diaspora's past in the present in order to place it in dialogue with literary and critical discourses on the French Caribbean.

Studies on memory have become particularly relevant to understanding postcolonial issues at work in the French Caribbean. The enduring wounds of the Holocaust and the resulting trauma of remembering such event sparked the prolific output on memory studies in recent years. Memories regarding the major traumatic events affecting the French Caribbean's past, namely slavery, continuously weave their way into present literary and critical discourses on this region. The fact that these memories continue to trouble the present signifies that they can be considered in terms of transgenerational trauma or what Hirsch calls "postmemory." She describes postmemory as a powerful form of memory "...because its connection to its object or source is mediated not through recollection but through an imaginative investment and creation" (659). More specifically, postmemory, according to Hirsch, characterizes "...the experience of those who grow up dominated by narratives that preceded their birth, whose own belated stories are evacuated by the stories of the previous generation, shaped by traumatic events that can be neither fully understood nor re-created" (659). In other words, postmemory operates at a temporal and spatial remove, which distinguishes it from survivor memory. It describes the persistent effects of a traumatic event as they are experienced by generations who did not actually experience the event. Given the basis of its formulation, creative writing becomes an apt forum to explore experiences of postmemory since "[i]t creates where it cannot recover. It imagines where it cannot recall. It mourns a loss that cannot be repaired" (Hirsch 664). As a fourth generation Indo-Guadeloupean, Moutoussamy, through postmemory, then writes East Indian historicity into the French Caribbean literary imagination through his works like Aurore.

Understanding the complexities of memory in the French Caribbean context begins with an understanding of its history. Edouard Glissant examines the intricate link between history and memory and explains that since French Caribbean history did not come together as part of a continuum but rather as a sudden shock, it constitutes, what he calls, a "nonhistory:" 
Les Antilles sont le lieu d'une histoire faite de ruptures et dont le commencement est un arrachement brutal, la Traite. Notre conscience historique ne pouvait pas 'sédimenter,' si on peut ainsi dire, de manière progressive et continue, comme chez les peuples qui ont engendré une philosophie souvent totalitaire de l'histoire, les peuples européens, mais s'agrégeait sous les auspices du choc, de la contraction, de la négation douloureuse et de l'explosion. Ce discontinu dans le continu, et l'impossibilité pour la conscience collective d'en faire le tour, caractérisent ce que j'appelle une non-histoire.

Le facteur négatif de cette non-histoire est donc le raturage de la mémoire collective. (Le discours antillais 223-24)

The result of dislocations and brutal ruptures, Glissant highlights, is that the French Caribbean becomes a place where collective memory has been effaced. This absence creates a gap that subsequent generations struggle to return to and fill. Repossessing the historical void and working through the obsession with the past in the present become, according to Glissant, the duty of the writer. Glissant then calls on French Caribbean writers to engage in what he calls a prophetic vision of the past, through which they can reconstitute French Caribbean history in their writing. The French Caribbean writer must then, in Glissant's words, dig deep into the collective memory and follow the latent signs that $\mathrm{s} /$ he has recuperated in his/her reality (Le discours antillais 227-28). He continues to suggest that French Caribbean writers' works have a remedial function as they identify and attempt to work through and come to terms with a painful moment in French Caribbean history in order to move forward into the future. Writing about the past then works through a double directional memory in the sense that it looks backward in order to move forward. Thus, Moutoussamy places the East Indian diaspora as a significant aspect of French Caribbean historicity and collective memory through his concept of Indianité and his works detailing the East Indian diaspora's displacement and its subsequent attempts to take root, both physically and culturally, in its new homeland. Similarly, his works can be read as a privileged site of postmemory, as previously defined by Hirsch. Moutoussamy and, by extension, his protagonist, Râma, can also be considered as agents of postmemory, that is, "... someone who gives narrative shape to the surviving fragments of an irretrievable past" (Hirsch 666).

Aurore recounts the story of Râma, a Brahmin or upper class born East Indian who is arranged to marry Aurore. But he falls in love with 
a pariah girl, Sarah, and is rejected by his mother for his transgressions. With a dismal future prospect in India, Râma and Sarah decide to leave and work as indentured laborers in Guadeloupe. On his arrival, Râma finds out that Sarah died aboard the ship. The novel ends with Râma reconciling with his former fiancée, Aurore, who now calls herself Citha. In the novel, Moutoussamy locates the East Indian diaspora's historicity in reference to slavery. Though indentureship was different from slavery, primarily because the former entailed contractual recruitment and allowed repatriation, the two systems often converged, since attitudes and disciplinary methods remained largely unchanged despite pressures from abolitionists. Glissant, for instance, describes the close connection between the two systems indicating that “....après 1848 , les pays de la Caraïbe sont partiellement peuplés de ces migrants hindous à qui on a fait croire qu'ils trouveraient du travail et qui ont été purement et simplement traités comme des esclaves" (Introduction à une poétique du divers 18). Like slaves, the indentured laborers were subjected to inhumane living conditions and exploitation whereby their value was compromised in order to protect the economic interests of the plantation system.

In Aurore, the narrator highlights these convergences by referencing images reminiscent of slavery. For instance, East Indian religious authorities denounce indentureship saying, "[d]ans les temples, les swamis ${ }^{1}$ identifiaient les Blancs au démon et parlaient de leur ruban bleu, blanc, rouge comme étant une corde de pendu, une chaîne d'esclavage" (58). Likewise, this image of the slave chain reemerges aboard the ship when one of the novel's characters, Govindin, overtaken by fear of his unknown future in a foreign land and nostalgia for his homeland, sees a ship returning to India and decides to jump overboard to swim to it. The narrator indicates that Govindin breaks "ses chaînes invisibles" and dives into the water (88). The repetition of the figurative chain not only alludes to the system of servitude characteristic of slavery as well as the literal chains to which the slaves were attached during transportation but also to the metaphorical link that connects slavery and indentureship. Elsewhere in the novel, the narrator continues to situate the East Indian's plight aboard the ship in terms of the conditions of slavery, highlighting that those under slavery were worse. The narrator says “...l'Afrique - continent orphelin de millions d'hommes qui pendant des siècles avait livré ses fils aux négriers et au colonialisme dans des cales encore plus sinistres" (93). These references to and comparisons between the two systems of labor suggest that the East Indian diasporic experience is not read in isolation, but rather placed within the web of events shaping French Caribbean history. 
Moreover, the narrator employs images of travel and crossings, which reinforce the link between the two systems. En route to Guadeloupe, the narrator specifies that men and women were separated, and the boat symbolically transformed into an imprisoning vessel. They were extremely restricted in their mobility and were punished for the slightest offense. Furthermore, the conditions aboard the boat occasioned sickness and even death of several of the laborers, including Râma's first wife, Sarah. These conditions incite Râma to ask the captain, "Sommes-nous des voyageurs ou des prisonniers?" (80). Later in the novel, the narrator indicates that the violence associated with slavery was still evident: "Dans le désert des rêves des damnés, la vigilance était de tous les instants, le fouet claquait encore comme au temps de l'esclavage" (109). These evocations of slavery signify the establishment, on Moutoussamy's behalf, of narrative dialogues between the two systems founded on shared physical violence and sufferings that move beyond racial and cultural borders. They enable Moutoussamy to situate the East Indians' experience within the French Caribbean historical context and to measure its relation with the other diasporas, namely the African diaspora in the French Caribbean.

However, the narration underscores the differences between the two systems, thereby highlighting the sui generis nature of the East Indian diaspora's experience that cannot be fully subsumed under the category of slavery. These distinctions carve out a symbolic space for the East Indian diaspora in French Caribbean history and memory. Though there were reports of kidnappings and deceptive recruitment methods, the East Indians, for the most part, had the opportunity to choose whether or not they wanted to leave India or remain there. This was a complex choice since either decision brought its own set of difficulties for the laborers. Another major difference between the two systems was that the indentured laborers, unlike the slaves, had the possibility of maintaining contacts amongst themselves, which allowed them to create fraternal bonds and preserve a profound spiritual attachment with their homeland, India. Likewise, the indentured laborers had the right to repatriate at the end of their contract, a right that was not offered to slaves.

From the beginning of Aurore, India, and specifically the town Ipsala, where Râma and his mother lived, is represented as poverty-stricken and ill-fated. Râma and his mother, Lila, survived the deaths of several family members and Râma remains his mother's last surviving hope. Lila arranges the marriage between Râma and Aurore, a marriage that was initially arranged by Râma's and Aurore's fathers since their childhood. But although Râma is obligated to marry Aurore, he falls in love with Sarah. Sarah, however, belongs to the Untouchable class whereas Râma is part 
of the upper class. In accordance with social codes regarding inter-caste relations, Râma is forbidden from interacting with Sarah. Nevertheless, he breaks the caste system tradition, risks his relationship with his mother, and decides to meet with Sarah. Their encounter is brief, but unbeknownst to Râma, Lila observed this meeting and is infuriated. On returning to his home, Lila chases Râma out for having broken conventional societal codes and Râma becomes a social outcast. Râma's story can be viewed as a metaphor for the story of poverty-stricken outcasts rejected by mother India. The complexity of their situation, whereby the precarious social and economic circumstances in India impelled these characters to search for a better life elsewhere, calls into question the indentured laborers' willingness to leave their homeland. In fact, the narrator indicates that despite poverty, the Indian held on to his family, his country and his roots and that "[s]euls les hors-la-loi, les paresseux, les indésirables et ceux qui comme Râma avaient commis de lourdes fautes étaient candidats au grand voyage" (58). On the one hand, leaving India and crossing the ever-feared black waters or the kala pani provoked ominous feeling of cultural defilement and betrayal. On the other hand, staying in India subjects these outcasts to a life of misery and atrocious living conditions. Caught between the dynamics of attraction and repulsion, philia and phobia, these outcasts had to choose between the dreaded reality of life elsewhere or death at home. In this light, Râma's expulsion by his mother from their home symbolically parallels mother India's expulsion of her "children" from the national home. These "mothers" can, therefore, be regarded as discriminatory and ostracizing, rejecting their "children" and condemning them to servitude.

Moreover, the ship constitutes an important element of the East Indian diaspora's experience of exile. It initially represented a space of imprisonment that occasioned separation from India. However, the vessel symbolically transforms into a birthing space that created fraternal bonds amongst the laborers once they set sail for their new destination. When the characters in Aurore begin to leave India, their cheering quickly transforms into a profound silence: "Le pont devint silencieux. [...] La séparation emplie de silence suspendit un instant le temps" (73). This silence signifies the onslaught of nostalgia, fear, guilt, and doubt that the East Indians experienced throughout their journey to the New World. Similarly, aboard the Aurélie, the name of the ship transporting the East Indians in Aurore, the narrative voice recounts the slow separation between the laborers and their homeland: "Avec la permission d'une légère brise, le bateau décolla doucement son flanc de la jetée" (73). The ship and its movement symbolize the geographic displacement and distancing from India. Its 
slowness intensifies the painful effects of this separation. Moreover, the narrator indicates that the men and women had to live in dark and confined spaces that were "moins de deux mètres cubes d'espace," which made "l'atmosphère par mauvais temps...insupportable car il fallait fermer une partie des prises d'air" (79). These stifling conditions coupled with the obscurity of the ship's hold defined the indentured laborer's exilic experience aboard the ship. However, the negative connotations of the challenging circumstances onboard are undermined by the fact that they occasioned the creation of fraternal bonds among the laborers. This fraternity, which is generally referred to as the Jahaji bhai or ship-brotherhood bond, was born out of shared emotional and physical difficulties experienced during their journey. In Aurore, the ship's hold can be interpreted as a symbolic, collective uterus that provides a source of comfort in the face of violence and exploitation. The narrator states "[i]ls étaient tous sur le même bateau comme des jumeaux dans le même utérus" (77), and later in the novel, the sea is described as "une berceuse" (82). Moreover, social and religious differences that separated the East Indians in India were dissolved aboard the ship, as the narrator highlights: "le musulman et l'hindou, le brahmane et l'intouchable mêlèrent leurs souffles qui emportèrent d'un coup tous les tabous et interdits ayant résisté aux siècles" (78). The indentured laborers, therefore, posited themselves as a homogenous unit that found common ground in their shared physical and psychological sufferings experienced during their journey to the New World. Evidently, they redefine themselves through relationships of equality and solidarity rather than social rankings or religious classifications. The communal bonds fostered aboard the ship then rendered this space a microcosm of the communal dynamic that continued to develop once the East Indians arrived in Guadeloupe. Indeed, these initial bonds became an instrument that fostered imaginary constructions of India and the creation of a fixed East Indian identity that resisted cultural assimilation.

In his attempt to resist cultural assimilation in Guadeloupe, Râma, guided by his elder, Gopi, mobilizes the community of indentured laborers to regenerate the East Indian culture and, by extension, East Indian identity. On his arrival to Guadeloupe in 1884, Râma immediately notes the absence of the East Indians' imprint in the community even though they had been living there for thirty years: "Mais dans les plaines aussi mornes que l'océan, dans les vallées aussi profondes que les creux des vagues, point de pagode ni de temple! L'horizon ne refléta que l'écho muet du temps. Où sont-ils nos pères? Qu'est devenue l'Inde depuis trente ans sur cette terre ?" (108). Together with the other East Indians, Râma is 
encouraged to revive the presence of India and the East Indian identity in Guadeloupe: "De la fournaise, une petite corolle de têtes unies et hardies se donna comme mission de déchirer la monotonie des ans et des jours, et de harceler l'identité indienne" (130-31). The re-launching of the East Indian identity is accomplished by the observance of religious practices as well as the staging of traditional rites, specifically, the Fête du Pongal, which ceased to be celebrated for more than twenty-five years due to its repression and eventual prohibition by French authorities. In this respect, the celebration is seen as an inaugural event in the re-launching of the East Indian identity and culture amongst the laborers. It is presented in a theatrical and extravagant way, with detailed descriptions of the rites, outfits, music, songs, and dances that occupy more than one-half of a page of the physical text:

Après vingt-cinq ans de silence, la fête commença. Sous le ciel tropical étoilé choisi comme dais, musiciens, chanteurs et danseurs commandés par Abo entrèrent en scène. Des costumes rapportés de l'Inde et précieusement conservé, couverts de brillants, de petites glaces et de papiers de couleurs, véritables reliques, trouèrent l'obscurité de leurs reflets. Avec des grelots aux chevilles et aux poignets, un kapou au nez et, sur la tête un narè orné de lamelles dorées et argentées, ceux qui n'avaient pas dansé depuis des années, le visage bardé d'émotion, rythmèrent les chansons retrouvées avec aisance et harmonie. Derrière un talé fait plusieurs morceaux de jute, les figures gaies de Kourokol, Komali et Katiékalin ranimèrent la soirée au moment où elle allait sombrer dans la monotonie. Pendant que l'on mimait des scènes du Raja Tesingou Natakam, du Nallatanga ou du Madouraï Viram, Râma, papillonnant dans l'assemblée s'efforça de communiquer à chacun la pincée de sel qu'il avait perdue. (132; italics in original)

As Lawrence Fontaine-Xavier highlights in his article, "Discours informatif, écriture du réel: la mise en scène des rites pour dire l'identité," these precise details on the ethnic particularity create an effect of authenticity, which corresponds with Râma's quest for an authentic identity. In addition, the pomp of the celebration insists on the regeneration of the collective identity of the diasporic East Indians. It is also worth noting that from the decision to celebrate the Fête du Pongal, the narrator focuses on the preparation and final proceedings of the Fête. The 
meticulous organization can, therefore, suggest that identity formation in exile is an entire process that can begin with returning to one's origins.

Moreover, the meeting place for the ceremony represents a communal space of fraternity where "...des coolies venus de toutes les habitations" met to clear off "...un espace de quatre ares environ" (131). The clearing off of the land to make it their own reflects their attempt to negotiate geographical space, thereby making Guadeloupe their homeland: "Qu'elle [la Guadeloupe] soit notre mère-patrie et la fille de l'Inde" (132). This question of self-reconstruction is additionally reinforced by the narrator's revelation that the East Indians “...bris[èrent] la coupe de venin des maîtres. [...] [et] ouvrirent alors les yeux avec la volonté de croire à l'aurore" (132; emphasis added). The "aurore" or "dawn" of the novel's title not only alludes to Râma's first fiancée's name, but also symbolizes the metaphorical rebirth of a new history in this foreign space, an awakening that is achieved by the appropriation of geographical space as well as by the return to the disappearing East Indian practices. To further corroborate this idea of returning to past cultural heritage to redefine the East Indian community's present identity, Râma's reconciliation with Aurore at the end of the novel is revealing. Since Aurore was prescribed to marry Râma since his childhood, she can be considered as a symbol of a purist East Indian cultural tradition. Râma's reunion with her and his rejection of other East Indian women in Guadeloupe implies, therefore, his return to East Indian cultural heritage in a foreign land.

Indeed, these initial communal bonds fostered aboard the ship and developed through the interactions occurring during the commemoration of the East Indian festivities become an instrument that nurtured imaginary constructions of India, and the creation of a fixed East Indian identity that resisted cultural assimilation. While this re-establishment certainly carves out a space for the East Indian identity in French Caribbean historicity and literary discourses, the following section challenges its implications, highlighting that it can lead to a self-imposed alienation or what Karyn H. Anderson sees as the positing of ".... a center/periphery dichotomy within the heart of the periphery" (30).

In Aurore, the neem plant comes to symbolize the auto-marginalization of the laborers. The narrator indicates that Gopi, one of the first laborers to arrive in Guadeloupe planted this tree on his arrival. Originally from India, this sacred tree that stays green throughout the year has the capacity to adapt to unfavorable conditions and is well known for its medicinal and therapeutic properties (Moutoussamy, La Guadeloupe 87). Characterized as a single root tree, the neem plant opposes the Glissantian 
rhizome root symbol for relational possibilities of French Antillean identity paradigms and instead echoes Césaire's image of a single fixed root. Since the neem plant strongly evokes India, and by extension a diasporic center, its single root implies an essentialist conception of identity based mainly on the imaginary return to India. This single root can then connote an umbilical cord that reconnects the East Indian diaspora to India from its new homeland. Furthermore, the rural space surrounding the neem tree represents a communal space where the East Indian community recreates their cultural life from India in Guadeloupe. Being among other East Indians, coupled with the memory of their motherland and their Tamil language, the displaced East Indian community is able to rekindle its East Indian identity and spiritually revisit India.

The subsequent reconstruction of a collective East Indian identity, which transcends social class hierarchies, is based on the shared physical and psychological difficulties of geographic displacement. Thus, the monthly meetings held in the vicinity of the neem plant allow the characters to forget, even if only momentarily, the grind of their daily living in the sugarcane fields, and to live temporarily in their East Indian identity. This space then provides a therapeutic value, which corresponds directly to the healing properties of the neem plant. Under this shady tree, the characters can metaphorically take shelter from their physical and psychological pains to cure themselves of the difficulties they encounter from their work on the sugarcane fields. The neem tree can equally function as a symbolic shelter that protects the East Indian past. Additionally, if considered as a metaphor for the population of East Indian origin living in Guadeloupe and their culture, the indication that this tree has been planted and flourishing for thirty years suggests the resilience of this population and its culture that can survive as well as adapt to a foreign land. However, this idea of survival is undercut by the fact that the neem plant as well as statues of the Hindu Goddess Mariémin are hidden "à l'abri de tout regard" (126). While the laborers could only have practiced their culture and religion in hiding, due to the prohibitions of the former colonizers, the fact that they isolate themselves in the countryside raises the question of whether this East Indian culture displaced in Guadeloupe can, perhaps, only exist in a marginal and isolated space. Therefore, while the retention of East Indian cultural heritage manifests itself as a valorizing power for the Indo-Guadeloupian population, it can also be read as alienating. As this community retreats into past myths and restores lost traditions, its interactions with the surrounding diversity become limited and almost non-existent. The novel closes with Râma and Aurore's marriage ceremony and the indication of a 
new beginning: "A Zévalos, sous le bambou, Gopi célébra le mariage de Râma et d'Aurore. Un autre siècle commença" (175). The union, symbolic of this restoration of East Indian cultural traditions, ushers in a new era. The possibilities that this new period brings to the East Indian identity, however, is left to the reader's imagination. While Râma establishes an East Indian diasporic identity, it is unclear how this identity positions itself within the broader Guadeloupean cultural and racial diversity.

As agents of post-memory, both Moutoussamy and his protagonist, Râma, recuperate the East Indian diaspora's exilic experience. The novel itself also serves as a material inscription of the East Indian physical and cultural presence in the French Caribbean. It becomes part of the cultural production that writes this diaspora's experience into French Caribbean memory and history by positioning it in relation to slavery while simultaneously underscoring its specificities. In Aurore, Râma strives to keep the East Indian cultural heritage alive in the post-slavery Guadeloupe. His story gives voice to the silenced and marginalized East Indian diaspora and ultimately commemorates its presence and material and immaterial cultural contributions to the diverse Guadeloupean society. Struggling between the polarities of cultural fixation and cultural annihilation, Râma ultimately chooses the former that is achieved through remembrance of fragments of memory and culture. This choice, however, proves to be problematic. It suggests a dismissal of the spatio-temporal shift that indentureship occasioned, and it seems to be recreating boundaries that contribute to the diaspora's already marginalized presence.

\section{Notes}

\section{A male Hindu religious teacher.}

2. A type of tiara.

\section{Works cited}

Anderson, Karyn H. "Ernest Moutoussamy's Aurore and the Construction of a Split-level Home." Florida Atlantic Comparative Studies Journal, vol. 11, 2008-2009, pp. 29-40.

Bernabé, Jean, Patrick Chamoiseau and Raphaël Confiant. Eloge de la Créolité. Trans. M.B. Taleb-Khyar. Baltimore: Johns Hopkins University Press, 1990.

Césaire, Aimé. Cahier d'un retour au pays natal. Paris: Présence africaine, 1983. 
Dash, J. Michael. "Exile and Recent Literature." A History of Literature in the Caribbean, ed. by A. James Arnold, Julio Rodríguez-Luis, and J. Michael Dash, vol. 1, Amsterdam: Benjamins, 1994, pp. 451-61.

Fontaine-Xavier, Lawrence. "Discours informatif, écriture du réel: la mise en scène des rites pour dire l'identité." Discours et écritures dans les sociétés en mutation, ed. by Manuel Bengoéchéa, Paris: L'Harmattan, 2007, pp. 123-34.

Glissant, Edouard. Introduction à une poétique du divers. Paris: Gallimard, 1996.

---. Le discours antillais. Paris: Gallimard, 1997.

Hirsch, Marianne. "Past Lives: Postmemories in Exile." Poetics Today, vol. 17, no. 4, Winter 1996, pp. 659-86.

Mehta, Brinda. "Indianités francophones: Kala Pani narratives." L'Esprit Créateur, vol. 50, no. 2, Summer 2010, pp. 1-11.

Moutoussamy, Ernest. Aurore. Paris: L'Harmattan, 1987.

---. La Guadeloupe et son Indianité. Paris: Éditions Caribéennes, 1987. 